\title{
Intracranial Hypertension and Intra-abdominal Pressure. Is it Worth Measuring?
}

\section{Hipertensão intracraniana e pressão intra-abdominal. Vale a pena mensurar?}

\author{
Simonei Bonatto ${ }^{1}$ Danielle Pacheco Matias ${ }^{2}$ Leonardo Christiaan Welling ${ }^{3}$ \\ 1 Postgraduation program, Universidade Estadual de Ponta Grossa, \\ Ponta Grossa, PR, Brazil \\ 2 Universidade Estadual de Ponta Grossa, Ponta Grossa, PR, Brazil \\ ${ }^{3}$ Neurological Surgery Department, Universidade Estadual de Ponta \\ Grossa, Ponta Grossa, PR, Brazil \\ Address for correspondence Leonardo C. Welling, MD, PhD, \\ Departamento de Neurocirurgia, Universidade Estadual de Ponta \\ Grossa, Rua Tiradentes, 976 Centro, Ponta Grossa, PR, Brazil \\ (e-mail: leonardowelling@yahoo.com.br).
}

Arq Bras Neurocir 2020;39(3):189-191.

Abstract
Keywords
- intra-abdominal
pressure
- abdominal
compartment
syndrome
- intracranial pressure
- intracranial

hypertension

Resumo

Palavras-chave

- pressão intraabdominal

- síndrome do compartimento abdominal

- pressão intracraniana

- hipertensão intracraniana
Patients with refractory intracranial hypertension who have already undergone all the measures recommended by the current guidelines can benefit from having their intraabdominal pressure monitored since its increase generates hemodynamic repercussions and secondary elevation of intracranial pressure. In this context, a bibliographic research was performed on PubMed with the terms intra-abdominal pressure, abdominal compartment syndrome, intracranial pressure, intracranial hypertension. Altogether, 146 articles were observed, 87 of which were from the year 2000, and only 15 articles were considered relevant to the topic. These studies indicate that patients with refractory intracranial hypertension can benefit from the measurement of intraabdominal pressure, since there is evidence that an increase in this pressure leads to organic dysfunctions with an indirect impact on cerebral venous return and, consequently, an increase in intracranial pressure. In those who underwent decompression laparotomy, direct effects were observed in reducing intracranial hypertension and survival.

Pacientes com hipertensão intracraniana refratária que já foram submetidos a todas as medidas preconizadas pelas diretrizes atuais podem se beneficiar do monitoramento da pressão intra-abdominal, uma vez que seu aumento gera repercussão hemodinâmica e elevação secundária da pressão intracraniana. Nesse contexto, realizou-se uma pesquisa bibliográfica no PubMed com os termos "intra-abdominal pressure," "abdominal compartment syndrome," "intracranial pressure"; "intracranial hypertension." Ao todo, foram observados 146 artigos, dos quais 87 eram a partir do ano 2000, e apenas 15 artigos foram considerados relevantes ao tópico. Esses estudos indicam que pacientes com hipertensão intracraniana refratária podem se beneficiar da medida da pressão intra-abdominal, uma vez que existem evidências de que o aumento desta leva a disfunções orgânicas com impacto indireto no retorno venoso cerebral e, consequentemente, no aumento da pressão intracraniana. Naqueles que foram submetidos à laparotomia descompressiva, observou-se efeitos diretos na redução da hipertensão intracraniana e sobrevida. received

April 3, 2020

accepted

May 12,2020
DOI https://doi.org/

10.1055/s-0040-1713593. ISSN 0103-5355.
Copyright $\odot 2020$ by Thieme Revinter

Publicações Ltda, Rio de Janeiro, Brazil
License terms

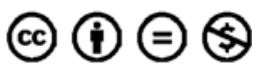




\section{Introduction}

The intracranial content is composed of brain tissue (80\%), cerebrospinal fluid (10\%), and blood (10\%). The maintenance of intracranial pressure (ICP) at its typical values depends on the preservation of intracranial volume. Any situation that causes an intracranial component to increase in volume requires a decrease in the other components so that there is no increase in ICP. The compensation process often occurs at the expense of decreasing the volume of liquor and blood, since the brain mass is less compressible. About $30 \%$ of the capacity to decrease the intracranial volume is represented by cerebrospinal fluid, which can be displaced into the subarachnoid spinal space or absorbed by arachnoid granulations. When compensation mechanisms are exhausted, ICP increases as a consequence. The increase in ICP, in turn, can cause a decrease in tissue perfusion, leading to an increase in cellular damage due to ischemia. An average ICP measurement ranges from 0 to $15 \mathrm{~mm} \mathrm{Hg}$, and values above $15 \mathrm{~mm} \mathrm{Hg}$ can be considered intracranial hypertension (ICH). However, not all patients have the same tolerance for increased ICP.

Intracranial hypertension is a clinical condition that affects many patients in the intensive care unit. Intracranial pressure monitoring provides information that facilitates interventions to prevent cerebral ischemia. ${ }^{1-3}$ Intra-abdominal pressure (IAP) is defined as the pressure inside the abdominal cavity, resulting from the interaction between the abdominal wall and the viscera inside it. Physiologically, the pressure undergoes slight oscillations according to the respiratory phase and the resistance of the abdominal wall. The physiological value in adults is up to $5 \mathrm{~mm} \mathrm{Hg}$; however, in patients with altered conditions without pathophysiological significance, such as obese individuals, it can range from 10 to $15 \mathrm{~mm} \mathrm{Hg}$; in critically ill patients, it is considered between 5 to $7 \mathrm{~mm} \mathrm{Hg}^{3-6}$

Intra-abdominal hypertension (IAH) is considered when an increased IAP ( $>12 \mathrm{~mm} \mathrm{Hg}$ ) is registered after three measurements at intervals of between 4 and 6 hours. Since it is gradual, it can progress to abdominal compartment syndrome (ACS), when IAP is maintained at levels higher than $20 \mathrm{~mm} \mathrm{Hg}$, associated with changes or organ failure., ${ }^{4,6}$ This topic was chosen because, despite all the available technology that is applied to care within an intensive care unit, several times, we come across this environment with patients presenting multisystemic aggravations. Among them, head and abdominal trauma and many times, these patients are in clinical condition with a progressive increase in ICP, which does not decrease with either surgical intervention or pharmacological measures (sedation with neuromuscular blocker associated with osmotic diuretics).

\section{Methods}

A bibliographic research in the online database PubMed was used to identify the correlation between the increase in IAP) with the increase in ICP) In the initial search, the titles and abstracts of the articles were considered for the broad selection of probable works of interest, highlighting the abstracts (of the articles that did not have accessible text) and the full texts of the articles, using the keywords as terms: intra-abdominal pressure, abdominal compartment syndrome, intracranial pressure; intracranial hypertension. The inclusion criteria were the texts that approached the topic (aiming to bring the discussion closer to our context), and texts published between 2000 and 2019. At the end of the research, 146 articles were found; after filters were applied for dates from 2000 to 2019, 87 articles remained; complete texts were available for 21 articles, and after excluding those that did not contain information relevant to the topic, a final sample of 15 articles were included.

\section{Discussion}

Through the analysis of the literature, it can be found that several physiological changes occur in neurologically severe injuried patients, both in clinical e polytrauma scenarios. These changes have a direct impact on various systems, both neurological and abdominal, which is the focus of this study. However, most of these articles bring the treatment of each system in isolation, not establishing a correlation in which the excessive increase in IAP can increase the increase in ICP, which, in turn, causes neurological damage that is often irreversible. ${ }^{2,4,7}$

The literature shows us that acute IAH)causes an increase in ICP due to increased pleural pressure, thus preventing venous return. The increase in chest pressure leads to an increase in central venous pressure (CVP), which increases the intrajugular pressure, consequently decreasing the venous return of the brain and increasing, even more, the ICP. ${ }^{8}$ This association between IAP and ICP is essential. It should be considered when treating patients with IAH at risk for brain injury. Cerebral perfusion pressure (CPP) will decrease due to an obstruction of cerebral venous flow caused by increased intrathoracic pressure (ITP) due to cranial displacement of the diaphragm in combination with reduced systemic blood pressure resulting from decreased preload and cardiac output. ${ }^{9-11}$

The acute increase in IAP causes a significant increase in ICP, and the CPP can be significantly reduced. Mechanisms proposed to explain this change include reduced blood flow to the lumbar venous plexus (leading to increased pressure in the cerebrospinal fluid [CSF]), increased pressure of carbon dioxide (PaCO2), and reduced cerebral venous return by the jugular system. ${ }^{12-14}$ This hypothesis meets and underlies the Monro-Kellie doctrine, in which states that the intracranial volume is equal to the volume of cerebral blood (3-10\%) plus the volume of CSF (8-12\%) plus the volume of brain tissue, which consists of more than $80 \%$ water. While the total intracranial volume remains identical, the ICP remains constant. There can be no increase in the volume of one of these components without a compensatory decrease in the two others. Thus, whenever there is an increase in IAP, there will be an increase in intrathoracic pressure, which reduces cerebral venous return through the jugular system, leading to an increase in cerebral blood volume and intracranial hypertension. $8,11,12$ In a study conducted by Joseph et al, they have monitored parameters of patients $(n=29)$ with head 
Table 1 Parameters before and after abdominal decompression

\begin{tabular}{|l|l|l|l|l|}
\hline & MAP $(\mathrm{mm} \mathrm{Hg})$ & ICP $(\mathrm{mm} \mathrm{Hg})$ & CVP $(\mathrm{mm} \mathrm{Hg})$ & $\mathrm{Cl}\left(\mathrm{L} / \mathrm{m}^{\prime} \mathrm{M}^{2}\right)$ \\
\hline Predecompression & $29.5 \pm 5.3$ & $30.0 \pm 4.0$ & $20.9 \pm 6.6$ & $4.6 \pm 1.2$ \\
\hline Postdecompression & $27.5 \pm 5.3$ & $17.5 \pm 3.2$ & $18.9 \pm 6.1$ & $4.7 \pm 1.4$ \\
\hline P-value & NS & $<0.0001$ & NS & NS \\
\hline
\end{tabular}

Abbreviations: $\mathrm{CI}$, cardiac index; CVP, central venous pressure; ICP, intracranial pressure; MAP, mean airway pressure.

trauma and sustained increase in ICP, even with surgical (decompressive craniectomy) and pharmacological (barbiturates) management. In their study, these patients were evaluated before and after performing decompression laparotomy, resulting in the data shown in - Table $\mathbf{1}$.

Through the monitoring analysis, it can be seen that after decompression laparotomy there was a slight reduction in mean arterial pressure, central venous pressure, and cardiac index; however, what calls attention is a $41.55 \%$ drop in the mean ICP value, demonstrating that abdominal surgical intervention in these patients was an impact factor for reducing ICP. ${ }^{9}$ A similar result was demonstrated by Dorfman et al, who, in his case report, submitted a 17-year-old patient with head trauma and subdural hematoma to laparotomy due to ICH refractory to decompressive craniectomy, use of barbiturates and mannitol. After abdominal decompression, there was an improvement in both ICP and ventilatory values and measurement of renal function. ${ }^{15}$

\section{Conclusion}

Based on the selected articles, it was possible to identify several systemic complications due to the increase in IAP. Among these complications, there was a direct correlation between the increase in IAP and the increase in ICP. Some studies direct the measurement of IAP when there are findings of ICP refractory to usual treatments such as decompressive craniectomy and pharmacological measures, thereby emphasizing the intervention of decompressive laparotomy as an adjunct in the treatment of refractory $\mathrm{ICH}$. What is also evident is the reflection that we may be underestimating patients with refractory ICP because we are not measuring IAP.

Conflict of Interests

The authors declare that there is no conflict of interests.

\section{References}

1 Citerio G, Vascotto E, Villa F, Celotti S, Pesenti A. Induced abdominal compartment syndrome increases intracranial pressure in neurotrauma patients: a prospective study. Crit Care Med 2001; 29(07):1466-1471
2 Giugno KM, Maia TR, Kunrath CL, Bizzi JJ. Tratamento da hipertensão intracraniana. J Pediatr (Rio J) 2003;79(04):287-296

3 Ferreira $\mathrm{CB}$, Bassi E, Lucena L, et al. Mensuração da pressão intracraniana e desfechos em curto prazo de pacientes com lesão encefálica traumática: Uma análise de propensão pareada. Rev Bras Ter Intensiva 2015;27(04):315-321

4 Bahten LCV, Lange PAL, Alves RFF, Soares HMN, Souza TM, Bahten ACV. Síndrome compartimental abdominal: análise do conhecimento da equipe médica de um Hospital Universitário de Curitiba. Rev Col Bras Cir 2018;45(03):e1884

5 Kamine TH, Papavassiliou E, Schneider BE. Effect of abdominal insufflation for laparoscopy on intracranial pressure. JAMA Surg 2014;149(04):380-382

6 Malbrain ML, De Laet IE, De Waele JJ, Kirkpatrick AW. Intraabdominal hypertension: definitions, monitoring, interpretation and management. Best Pract Res Clin Anaesthesiol 2013;27(02): 249-270

7 Deeren DH, Dits H, Malbrain MLNG. Correlation between intraabdominal and intracranial pressure in nontraumatic brain injury. Intensive Care Med 2005;31(11):1577-1581

8 Scalea TM, Bochicchio GV, Habashi N, et al. Increased intraabdominal, intrathoracic, and intracranial pressure after severe brain injury: multiple compartment syndrome. J Trauma 2007;62 (03):647-656, discussion 656

9 Joseph DK, Dutton RP, Aarabi B, Scalea TM. Decompressive laparotomy to treat intractable intracranial hypertension after traumatic brain injury. J Trauma 2004;57(04):687-693, discussion 693-695

10 Villaça MP, Mantovani M. Comportamento da pressão intracraniana, da perfusão cerebral e dos parâmetros hemodinâmicos durante a síndrome do compartimento abdominal em cães. Rev Col Bras Cir 2006;33(04):211-214

11 Zampieri FG, Almeida JR, Schettino GP, Park M, Machado FS, Azevedo LC. Factors associated with variation in intracranial pressure in a model of intra-abdominal hypertension with acute lung injury. Rev Bras Ter Intensiva 2011;23(02):164-169

12 Depauw PRAM, Groen RJM, Van Loon J, Peul WC, Malbrain MLNG, De Waele JJ. The significance of intra-abdominal pressure in neurosurgery and neurological diseases: a narrative review and a conceptual proposal. Acta Neurochir (Wien) 2019;161(05): 855-864

13 Milanesi R, Caregnato RCA. Intra-abdominal pressure: an integrative review. Einstein (Sao Paulo) 2016;14(03):423-430

14 Sosa G, Gandham N, Landeras V, Calimag AP, Lerma E. Abdominal compartment syndrome. Dis Mon 2019;65(01):5-19

15 Dorfman JD, Burns JD, Green DM, DeFusco C, Agarwal S. Decompressive laparotomy for refractory intracranial hypertension after traumatic brain injury. Neurocrit Care 2011;15(03):516-518 